\title{
A comparative Evaluation of Postharvest Quality Attributes of Two Banana (Musa spp) Varieties as Affected by Preharvest Production Conditions
}

\author{
J. Ambuko ${ }^{1}$, Y. Sekozawa ${ }^{2}$, S. Sugaya ${ }^{2} \&$ H. Gemma ${ }^{2}$ \\ ${ }^{1}$ Department of Plant Science and Crop Protection, University of Nairobi, Kenya \\ ${ }^{2}$ Laboratory of Pomology, Graduate School of Life and Environmental Sciences, Tsukuba University, Tsukuba, \\ Japan \\ Correspondence: J. Ambuko, Department of Plant Science and Crop Protection, Faculty of Agriculture, University \\ of Nairobi, Kenya. Tel: 254-722-676-458. E-mail: ambuko@yahoo.com; jane.ambuko@uonbi.ac.ke
}

Received: September 13, 2012 Accepted: November 13, 2012 Online Published: February 17, 2013

doi:10.5539/jas.v5n3p170

URL: http://dx.doi.org/10.5539/jas.v5n3p170

\begin{abstract}
Preharvest factors including agro-ecological conditions, cultural practices and crop variety selection greatly impact fruit quality potential at harvest and postharvest longevity. In this study, quality attributes of banana fruits (Musa spp), cultivars 'Williams' and 'Grande naine' produced under low chemical production system (LCPS) and conventional production systems (CPS) in Ecuador were investigated. The fruits produced under the two production systems were evaluated for various physicochemical attributes including peel hue angle, firmness, moisture content, starch, soluble sugars and titratable acidity (TTA). Sensory evaluation by untrained panelists was done to compare the organoleptic attributes of the banana fruits. The results showed that 'Williams' bananas from the LCPS had better eating quality as evidenced by higher soluble sugars, less starch and lower firmness and higher moisture content of ripened fruits' flesh. 'Grande naine' bananas generally had higher levels of TTA compared to 'Williams' and in both cultivars LCPS bananas had higher TTA levels compared to CPS bananas. These quality attributes were affected by variability in climatic conditions during the year-long period of evaluation. Sensory panelists did not clearly discriminate between LCPS and CPS bananas but showed preference for 'Williams' bananas over 'Grande naine' bananas. These results show that banana variety, cultural practices and harvest season affect the banana quality attributes at harvest and affect the eating quality of the fruits.
\end{abstract}

Keywords: Musa spp, banana, organic, conventional, preharvest, postharvest, quality

\section{Introduction}

The effects of preharvest production factors including climatic, geographic and cultural practices on quality and postharvest characteristics of fruits and vegetables have been widely reported. These factors have been shown to affect the commodities' chemical composition, physical characteristic and nutritional quality. Seasonal variation in precipitation and temperature significantly affects the physicochemical characteristics and flavor attributes of the banana (Chillet \& de Lapeyre, 2002). In the tropical climatic conditions, the banana crop is exposed to the changing weather patterns throughout the year. In Ecuador, these conditions range from adverse dry conditions with no precipitation to excessive rainfall. These conditions variably affect fruit growth and development and the subsequent postharvest quality (Chillet et al., 2000). It is commonly accepted that commodities that contain high moisture have poorer storage characteristics (Thompson, 2003). Variation in temperatures across the seasons also has significant effect on plant development hence overall composition at harvest (Dantuma et al., 1983; Dantuma \& Thompson, 1983). Geographical factors including soil type and altitude have also been reported to significantly affect rheological properties, soluble sugars content and other flavor attributes in banana (Chillet \& de Lapeyre, 2002; Suzuno \& Ishida, 2005). Methods of cultivation, fertilizers, pesticides, quality of water for irrigation constitute cultural practices that affect fruit quality potential at harvest (Forster et al., 2002).

In the recent years consumers have developed increasing interest in organically produced food. As a result, organic production systems have achieved a high public profile and are seen as a legitimate alternative to the conventional systems of food production which are responsible for environmental and food safety problems. 
Organic production systems emphasize the use of renewable resources, land management that maintains natural soil fertility, water conservation, rich biodiversity and long-term sustainability (Plotto \& Narciso, 2006). It is for these reasons that organic products are becoming increasingly attractive to the consumer leading to shifts from conventional to organic or less chemical production systems in the major producing countries. The growing interest in organic foods has necessitated numerous studies comparing yield and quality aspects of organic and conventionally grown foods (Worthington, 2001; Baker et al., 2002; Forster et al., 2002; Rembialkowska, 2004). However, sufficient research has not been done to give satisfactory answers to claims of superiority with respect to safety and nutritional values of organic crops. Like other preharvest factors, cultural practices employed during production have a significant effect on fruits quality and postharvest characteristics (Nyanjage et al., 2000; Rembialkowska, 2003).

The objective of this study was to determine the effect of the production system; less chemical production system (LCPS) versus conventional production system (CPS) on the quality and sensory attributes of the banana. The study was conducted over a period of one year in bananas imported from Ecuador, which experiences a tropical climate pattern with seasonal variation. To establish variation in quality resulting from genetic differences, comparison was made between two popular dessert cultivars, 'Williams' and 'Grande naine'.

\section{Materials and Methods}

Bananas fruits (Musa spp., AAA group, Cavendish subgroup 'Williams' and 'Grande naine' were used in this study.

\subsection{Production Conditions}

The bananas used in the experiment were grown in Pichilingue which is a low altitude district of Ecuador. The experiment was conducted between 2005 and 2006. The bananas were harvested from selected commercial farms at the mature green stage and shipped to Japan under controlled atmosphere conditions to minimize metabolic activities during transit period, which was approximately 20 days. A comparison was made between two production systems in Ecuador; less chemical production system (LCPS) and conventional production system (CPS). The CPS production conditions in Ecuador include chemicals; fungicides for Black Sigatoka sprayed at least 21 times, herbicide 8 times, nematicides and insecticides are sprayed once in the production year. Nitrogenous, phosphatic and potassic fertilizers are applied at a rate of 800,200 and $900 \mathrm{Kg} / \mathrm{ha} /$ year respectively. The LCPS conditions include minimal application of fungicides for Black Sigatoka which are sprayed less than 15 times in the production year while no herbicides, nematicides nor insecticides are applied. Basically no chemical fertilizers are used except for intervention when plants show deficiency symptoms. The primary source of nutrients are organic in the form of humus which is applied at a rate of $100-300 \mathrm{Kg} / \mathrm{ha} / \mathrm{year}$ and EM Bokashi (effective microorganism), applied at a rate of $40-150 \mathrm{Kg} / \mathrm{ha} / \mathrm{year}$. Ecuador experiences year-round variation in climatic conditions with distinct dry and wet seasons (Appendix 1). During the dry spell, supplementary irrigation was done for bananas in both production systems.

\subsection{Laboratory Preparation of the Banana Fruit Samples}

Bananas produced under the two production systems (LCPS and CPS) were sorted for uniformity and homogeneity and then separated into two batches. The first batch was used for measurement of the initial parameters at the green stage (upon arrival in Japan, after approximately 21 days of shipping time). The second batch was treated with ethylene (1000 ppm) over a 24-hour period in a closed chamber. Thereafter ethylene was released from the chamber and the bananas allowed ripening gradually to the full ripe stage at ambient room conditions (Temperature $20 \pm 2{ }^{\circ} \mathrm{C}$ and $65-70 \%$ relative humidity). The experimental design used for the laboratory experiment was a completely randomized design with ten replicates for each of the parameters evaluated.

\subsection{Measurement of Physical and Physicochemical Parameters}

Ten fingers from each treatment were randomly sampled for evaluation of various physical and chemical evaluations. Measurements of color, firmness and water content were done on fresh samples of raw and ripened bananas. Thereafter the samples of the pulp were diced and frozen in liquid nitrogen and stored at $-80^{\circ} \mathrm{C}$ until the time for chemical analyses. Color was determined from 10 fingers randomly selected from the banana hands at the raw and ripe stage. A Konica Minolta Chroma meter (Model CR - 400/410) was used to take color measurements expressed by the Hunter $\mathrm{L}^{*}, \mathrm{a}^{*}$ and $\mathrm{b}^{*}$. Hue angle $\left(\mathrm{H}^{0}\right)$ was calculated using the equation $\mathrm{H}^{0}=$ $\tan ^{-1}(a, b) \times 180 / \pi$. Firmness was determined from a random sample of 10 fingers selected from different hands. A rheometer (NRM - 202J, Fudokgyo Co., Ltd) connected to a $3 \mathrm{~mm}$ diameter plunger with a conical (pointed) tip was used for the raw bananas peel/pulp and ripe banana peel, while a blunt-tipped $3 \mathrm{~mm}$ plunger was used for 
the ripe banana. The plunger was penetrated into the banana tissue (peel/pulp) at the rate of $50 \mathrm{~mm} \mathrm{~min}^{-1}$. Three locations on the equatorial zone of the fingers were used and the average value of firmness calculated as $\mathrm{Kg}$-Force. To determine moisture content, 2 grams of the pulp was oven-dried at $60^{\circ} \mathrm{C}$ until a stable dry weight was achieved. The moisture content was calculated as the percentage weight lost after drying. For evaluation of soluble sugars, the banana pulp was freeze-dried to a stable weight and then ground into a fine powder using a blender. One gram of this powder was extracted in $80 \%$ ethanol for 24 hours two times. The ethanolic extracts from the two extractions were pooled and vacuo-evaporated at $40^{\circ} \mathrm{C}$ to water phase. The solution was filtered through membrane filters $(0.45 \mu \mathrm{M}$ and then $0.2 \mu \mathrm{M})$ prior to injection into HPLC machine fitted with a differential Refractive Index Detector RI-101 and column NH 2P-50 4E, Shodex Japan. The sugars were separated using a mobile phase of acetonitrile:water $(75: 25)$ at a flow rate of $1.0 \mathrm{ml} / \mathrm{min}$ and compared with the standards of the major sugars (fructose, glucose and sucrose). The total sugars present in the sample was determined by summing the individual sugars. Titratable acidity was determined from 10 grams of banana pulp which was blended in $40 \mathrm{ml}$ of deionized water and then double-filtered through two layers of cheese cloth. The solution thereof was titrated with $0.05 \mathrm{~N} \mathrm{NaOH}$ until the end point. Titratable acidity was expressed as citric acid equivalent ( $\mathrm{g}$ citric acid per $100 \mathrm{~g} \mathrm{FW}$ ).

\subsection{Evaluation of Sensory Attributes}

Sensory evaluation was carried out by a group of untrained panelists drawn from the student population in the horticulture department of Tsukuba University. A representative sample of fully ripened bananas from each of the different batches was cut into pieces, avoiding the extreme ends of the fruit. The slices of banana were arrayed on anonymously labeled plates and presented to the panelists in a sensory booth. The panelists were provided with a score sheet on which they scored each sample (on a scale of 1 to 10), on the various sensory attributes including general preference (acceptance), sweetness, aroma and texture.

\subsection{Data Analysis}

Analysis of variance was performed on the data $(\mathrm{n}=10)$ from independent sampling times and means separated by Tukey's test at $\mathrm{P} \leq 0.05$.

\section{Results}

The results presented in the tables below are for independent month on month evaluation for each of the parameters in the two banana varieties ('Grande naine' and 'William') produced under the two production systems (LCPS and CPS).

\subsection{Soluble Sugars}

The profile of the individual soluble sugars (sucrose, fructose and glucose) (not reported) was not affected by any of the preharvest factors under investigation (production system, cultivar and season). However the preharvest factors had a significant impact on the total soluble sugars (Table 1). Bananas that developed during the wet season had relatively low soluble sugars content compared to those whose development and harvesting occurred during the dry season. Regardless of the season, bananas from the LCPS had relatively higher levels of the total soluble sugars content compared to CPS bananas; this was especially evident in 'Williams'. No clear cut cultivar differences in soluble sugars were observed, but in some months 'Williams' tended to have higher soluble sugars compared to 'Grande naine'.

\subsection{Moisture Content (MC) of Raw and Ripened Bananas}

In 'Williams', raw LCPS bananas generally had a lower MC compared to CPS bananas. On the contrary in the cultivar 'Grande naine', CPS bananas had higher MC in most instances (Table 2). In both cultivars, bananas whose development occurred during the wet season (harvested in May and June) generally had higher moisture content compared to those that developed and were harvested during the dry season. Ripened LCPS bananas had higher MC than CPS bananas, a trend that was especially evident in 'Williams' in both the dry and wet season bananas (Table 3). 
Table 1. Differences in total soluble sugars ( $\mathrm{mg} / \mathrm{g}$ fresh weight) of 'Williams' and 'Grande naine' as affected by production system, low chemical production system (LCPS) or Conventional Production System (CPS) during the period of evaluation

\begin{tabular}{lccccc}
\hline & Williams & & & \multicolumn{2}{l}{ Grande naine } \\
\cline { 2 - 3 } & LCPS & CPS & & LCP & CPS \\
\hline May & $145.4 \mathrm{~b}$ & $154.0 \mathrm{a}$ & & $141.6 \mathrm{~b}$ & $140.9 \mathrm{~b}$ \\
June & $211.3 \mathrm{a}$ & $192.4 \mathrm{~b}$ & & $215.8 \mathrm{a}$ & $214.6 \mathrm{a}$ \\
July & $158.5 \mathrm{c}$ & $178.9 \mathrm{~b}$ & & $187.9 \mathrm{ab}$ & $191.7 \mathrm{a}$ \\
Aug/Sept & $183.5 \mathrm{~b}$ & $175.0 \mathrm{c}$ & & $193.5 \mathrm{a}$ & $166.8 \mathrm{c}$ \\
Oct & $195.6 \mathrm{a}$ & $158.5 \mathrm{c}$ & & $182.6 \mathrm{~b}$ & $176.1 \mathrm{~b}$ \\
Nov & $189.2 \mathrm{a}$ & $182.6 \mathrm{ab}$ & & $175.5 \mathrm{~b}$ & $161.5 \mathrm{c}$ \\
Dec & $195.4 \mathrm{a}$ & $189.4 \mathrm{~b}$ & & $185.3 \mathrm{bc}$ & $183.8 \mathrm{c}$ \\
Jan & $198.2 \mathrm{a}$ & $194.3 \mathrm{a}$ & & $183.5 \mathrm{~b}$ & $180.2 \mathrm{~b}$ \\
\hline
\end{tabular}

The means were separated by Tukey's Test. Letters within the rows indicate differences in means among the 4 banana types at $\mathrm{P}=5 \%, \mathrm{n}=10$. Same letters within rows imply no significant difference in total soluble sugars.

Table 2. Differences in moisture content of raw pulp (\% of fresh weight) of 'Williams' and 'Grande naine' as affected by production system, low chemical production system (LCPS) or Conventional Production System (CPS) during the period of evaluation

\begin{tabular}{|c|c|c|c|c|}
\hline & \multicolumn{2}{|l|}{ Williams } & \multicolumn{2}{|c|}{ Grande naine } \\
\hline & LCPS & CPS & LCPS & CPS \\
\hline May & $74.26 \mathrm{c}$ & $74.82 \mathrm{~b}$ & $75.81 \mathrm{c}$ & $72.36 \mathrm{~d}$ \\
\hline June & $72.90 \mathrm{~b}$ & $73.34 a$ & $72.77 \mathrm{bc}$ & $72.36 \mathrm{c}$ \\
\hline July & $71.83 \mathrm{a}$ & $70.80 \mathrm{~b}$ & $70.71 \mathrm{~b}$ & $71.22 \mathrm{~b}$ \\
\hline Aug/Sept & $72.08 \mathrm{a}$ & $71.21 \mathrm{~b}$ & $69.94 c$ & $71.00 \mathrm{~b}$ \\
\hline Oct & $72.22 \mathrm{a}$ & $72.12 \mathrm{a}$ & $69.77 \mathrm{c}$ & $71.34 \mathrm{~b}$ \\
\hline Nov & $72.79 a$ & $71.31 \mathrm{c}$ & $70.77 \mathrm{~d}$ & $71.93 \mathrm{a}$ \\
\hline Dec & $71.60 \mathrm{a}$ & $71.63 \mathrm{a}$ & 71.71a & $71.54 \mathrm{a}$ \\
\hline Jan & $71.88 \mathrm{~b}$ & $70.59 \mathrm{c}$ & $73.47 \mathrm{a}$ & $73.65 \mathrm{a}$ \\
\hline
\end{tabular}

The means were separated by Tukey's Test. Letters within the rows indicate differences in means among the 4 banana types at $5 \%$ level, $n=10$. Same letters within the rows imply no significant difference in means.

Table 3. Differences in moisture content of ripe pulp (\% of fresh weight) of 'Williams' and 'Grande naine' as affected by production system (LCPS and CPS)

\begin{tabular}{lccccc}
\hline & \multicolumn{1}{l}{ Williams } & & \multicolumn{3}{l}{ Grande naine } \\
\cline { 2 - 3 } \cline { 5 - 6 } \cline { 5 - 6 } & LCPS & CPS & & LCPS & CPS \\
\hline May & $75.60 \mathrm{a}$ & $75.80 \mathrm{a}$ & & $76.00 \mathrm{a}$ & $73.97 \mathrm{~b}$ \\
June & $74.52 \mathrm{c}$ & $74.97 \mathrm{~b}$ & & $75.84 \mathrm{a}$ & $73.97 \mathrm{~d}$ \\
July & $73.16 \mathrm{a}$ & $72.67 \mathrm{~b}$ & & $73.20 \mathrm{a}$ & $72.83 \mathrm{ab}$ \\
Aug/Sept & $73.45 \mathrm{a}$ & $71.85 \mathrm{c}$ & & $72.09 \mathrm{bc}$ & $72.54 \mathrm{~b}$ \\
Oct & $73.21 \mathrm{a}$ & $73.03 \mathrm{a}$ & & $71.99 \mathrm{~b}$ & $72.75 \mathrm{a}$ \\
Nov & $73.58 \mathrm{a}$ & $73.10 \mathrm{~b}$ & & $72.73 \mathrm{c}$ & $72.58 \mathrm{c}$ \\
Dec & $74.38 \mathrm{a}$ & $73.03 \mathrm{~b}$ & & $72.10 \mathrm{c}$ & $72.50 \mathrm{c}$ \\
Jan & $73.82 \mathrm{c}$ & $73.03 \mathrm{~d}$ & & $74.72 \mathrm{a}$ & $74.34 \mathrm{~b}$
\end{tabular}

The means were separated by Tukey's Test. Letters within the rows indicate differences in means among the 4 banana types at $5 \%$ level, $n=10$. Same letters within the rows imply no significant difference in means 


\subsection{Titratable Acidity (TA)}

Evaluation for TA was only done for bananas from the dry season. In both cultivars, LCPS bananas tended to have higher TA than CPS bananas. 'Grande naine' generally had higher levels of TA compared to 'Williams' (Table 4).

Table 4. Differences in titratable acidity (g citric acid equivalent per 100g FW) as affected by production system and cultivar

\begin{tabular}{llllll}
\hline & \multicolumn{2}{l}{ Williams } & & \multicolumn{2}{l}{ Grande naine } \\
\cline { 2 - 3 } \cline { 6 - 6 } & LCPS & CPS & & LCPS & CPS \\
\hline Aug/Sept & $0.267 \mathrm{c}$ & $0.269 \mathrm{c}$ & & $0.297 \mathrm{a}$ & $0.282 \mathrm{~b}$ \\
Oct & $0.260 \mathrm{~b}$ & $0.265 \mathrm{~b}$ & & $0.290 \mathrm{a}$ & $0.279 \mathrm{a}$ \\
Nov & $0.271 \mathrm{bc}$ & $0.262 \mathrm{c}$ & & $0.294 \mathrm{a}$ & $0.282 \mathrm{~b}$ \\
Dec & $0.299 \mathrm{a}$ & $0.273 \mathrm{~b}$ & & $0.301 \mathrm{a}$ & $0.294 \mathrm{a}$ \\
Jan & $0.301 \mathrm{a}$ & $0.277 \mathrm{~b}$ & & $0.297 \mathrm{a}$ & $0.299 \mathrm{a}$ \\
\hline
\end{tabular}

The means were separated by Tukey's Test. Letters within the rows indicate differences in means among the 4 banana types at $5 \%$ level, $n=10$. Same letters within the rows imply no significant difference in means.

\subsection{Firmness}

Ripened CPS bananas exhibited higher pulp firmness compared to LCPS bananas (Table 5). There were no distinct differences between the two cultivars.

Table 5. Differences in ripe pulp firmness (Kilograms force $-\mathrm{KgF}$ ) as affected by production system (LCPS and CPS) and cultivar (Williams and Grande naine)

\begin{tabular}{llllll}
\hline & \multicolumn{2}{l}{ Williams } & & \multicolumn{2}{l}{ Grande naine } \\
\cline { 2 - 3 } \cline { 6 - 7 } & LCPS & CPS & & LCPS & CPS \\
\hline May & $0.071 \mathrm{~d}$ & $0.085 \mathrm{~b}$ & & $0.079 \mathrm{c}$ & $0.094 \mathrm{a}$ \\
July & $0.105 \mathrm{a}$ & $0.103 \mathrm{a}$ & & $0.077 \mathrm{c}$ & $0.096 \mathrm{~b}$ \\
Aug/Sept & $0.090 \mathrm{c}$ & $0.106 \mathrm{a}$ & & $0.099 \mathrm{~b}$ & $0.104 \mathrm{a}$ \\
Oct & $0.111 \mathrm{a}$ & $0.109 \mathrm{a}$ & & $0.108 \mathrm{a}$ & $0.111 \mathrm{a}$ \\
Nov & $0.111 \mathrm{~d}$ & $0.122 \mathrm{c}$ & & $0.126 \mathrm{~b}$ & $0.129 \mathrm{a}$ \\
Dec & $0.088 \mathrm{~b}$ & $0.096 \mathrm{a}$ & & $0.090 \mathrm{ab}$ & $0.094 \mathrm{ab}$ \\
Jan & $0.093 \mathrm{ab}$ & $0.097 \mathrm{a}$ & & $0.090 \mathrm{~b}$ & $0.091 \mathrm{~b}$
\end{tabular}

The means were separated by Tukey's Test. Letters within the rows indicate differences in means among the 4 banana types at $5 \%$ level, $\mathrm{n}=10$. Same letters within the rows imply no significant difference in means

\subsection{Sensory Evaluation}

The panelists did not show any particular preference for LCPS or CPS bananas. However the panelist preferred 'Williams' bananas to 'Grande naine' in most of the sensory attributes scored (Figure 1). 
$\square$ Williams - LCPS $\square$ Williams - CPS $\square$ Grande naine - LCPS $\square$ Grande naine - CPS

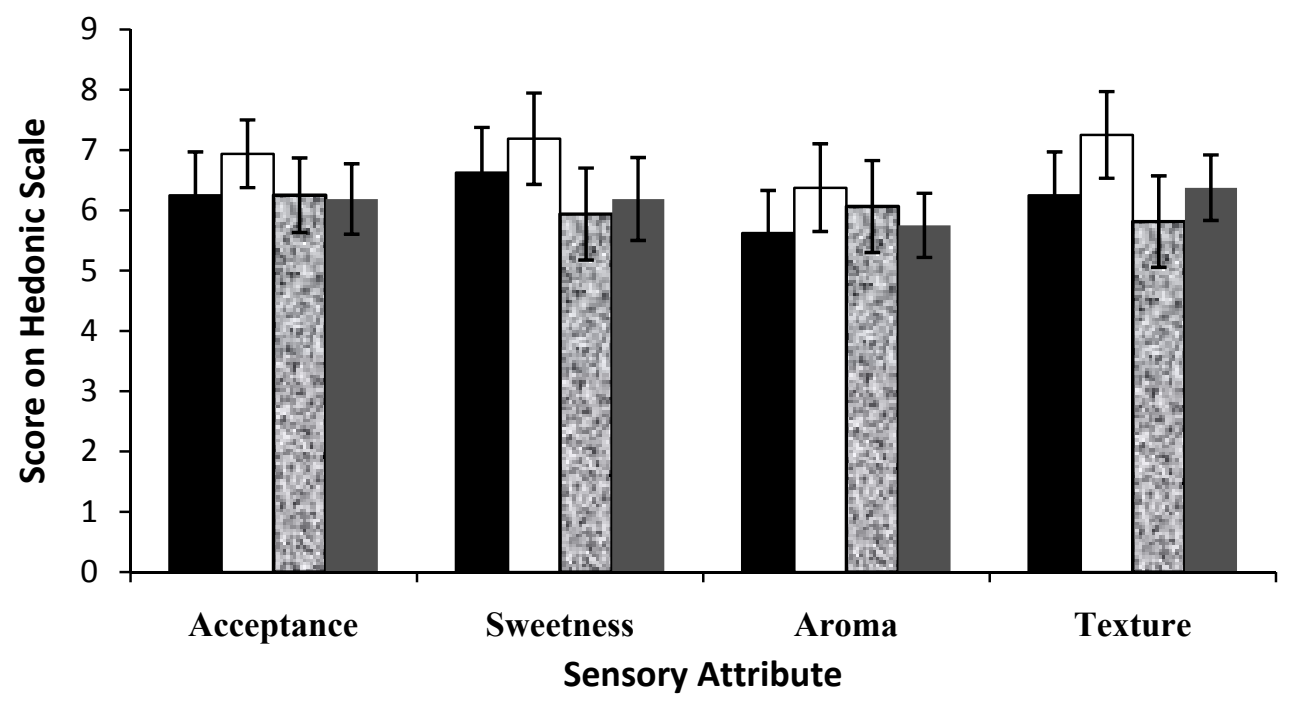

Figure 1. Hedonic scale scores by untrained panelists on 4 sensory attributes of 'Williams' bananas produced under two production systems (LCPS and CPS). Vertical bars indicate SE $( \pm)$ of means $(n=23)$

\section{Discussion}

Increased consumer concerns about food safety and environment has led to shifts from traditional conventional production systems (CPS) to organic or less chemical production systems (LCPS). The growing interest in organic foods has necessitated numerous studies making comparisons on yield and quality aspects of organic and conventionally grown foods (Worthington, 2001; Baker et al., 2002; Forster et al., 2002; Rembialkowska, 2004). Some of the reports that elevate organic over conventionally produced foods have been disputed by opponents who claim that the observed differences or variability emanated from secondary factors. In this study, arguments for the superiority of LCPS over CPS bananas were made in similar cultivars, grown during the same season and in the same geographical region. While instrumental evaluation of quality attributes comparing CPS and LCPS showed that the latter had some superior quality attributes as evidenced by higher soluble sugars, lower flesh firmness and higher succulence of ripened bananas, the sensory panelists did not show any preference for LCPS bananas. This shows that the preference for organic (or LCPS) bananas (and other commodities) by consumers is more about perceived better quality.

The quality of fruits can be evaluated from flavor, textural and nutritional attributes. Flavor is a combination of the basic tastes (salty, sweet, sour and bitter), mouth feel and aroma (Meilgaard et al., 1991). Perception of fruit and vegetable flavor is a composite of sensory responses resulting from compounds such as acids, sugars, volatiles and many other compounds. On the other hand, texture is generally defined as the overall feeling that a food gives in the mouth and depends on biochemical components such as lipid content, cell wall content and composition, particle size and shape, moisture content and mechanical. Accumulation of the compounds and attributes that affect flavor and texture during development as well as dynamic changes during ripening and/or senescence are determined preharvest factors including climatic, genetic and cultural practices are known to impact produce development and quality (Mattheius \& Fellman, 1999; Sams, 1999).

Climatic factors including rainfall, temperature and light intensity have a strong influence on the on plant growth and postharvest quality (Kader, 2002). Therefore the season and agro-ecological conditions in which plant grow will affect fruit quality attributes. In the present study, the seasonal variations within any given production year in Ecuador exposes the growing banana plants to different weather conditions resulting in a variety of effects on the harvested fruit. Wet season bananas in this study refer to those in which fruit development, from flowering until harvesting occurred fully or partially in the wet season (from late December to April). While those defined as dry season bananas developed partially or entirely during the dry period between June to early December. It takes approximately 12 weeks from flowering to harvesting in the wet season and 14 weeks in the dry season. The shorter fruit development period is attributed to the wet and warm conditions which prevail during the wet 
season, thereby promoting faster growth and development. Seasonal variation in soluble sugars, starch and pulp moisture content were observed in this study. Generally there were higher levels of soluble sugars, starch, titratable acidity and lower moisture content as the dry season progressed from the month of June to December. Limited water availability for plant uptake from the soil coupled with high evapotranspiration during the dry season could have resulted in water stress. Severe water stress may result in reduced yields and negatively impart fruit quality attributes; increased firmness and leathery texture (Thompson, 2003). However, moderate water stress as that characteristic of the dry period in Ecuador may have a positive effect on other quality attributes including increased soluble solids, acidity and ascorbic acid (Thompson, 2003). Studies in many fruits indicate that moderate water stress reduces fruits size but increases contents of soluble solids, acidity and ascorbic acid (Kader, 2002). On the other hand, excess water supply could result in high moisture content in fruit tissues leading to excessive turgidity, reduced firmness and reduced soluble solids content (Kader, 2002). In the present study, high pulp moisture content and lower pulp firmness were observed when fruit development occurred in the wet season. Moisture availability during fruit growth has been reported to affect fruit flavor. Melons irrigated prior to harvest had reduced flavor ratings by the sensory panelists. This was attributed to lower soluble solids concentration, greater fruit volume and greater moisture content (Lester et al., 1994). Apart from rainfall, temperature is another climatic factor that has a direct influence on metabolism and therefore indirectly affects cellular structure and other components which affect fruit quality. Temperature influences the uptake and metabolism of mineral nutrients as it affects transpiration. Previous studies indicate a high correlation between fruit temperature and firmness in apples (Blanpied et al., 1978), strawberries (Rose et al., 1934), and pears (Hartman, 1924) with lower temperatures resulting in higher firmness. In the present study, fruits that developed during the dry and relatively cool season exhibited higher firmness of the flesh, confirming earlier reports. Temperature variation has been shown to affect dry matter accumulation and fruit composition (Hewlett, 2006)). Low temperatures experienced during the dry season may have contributed to higher dry matter accumulation during banana development, which probably contributed to higher soluble sugars reported. On the other hand, the lower soluble sugar levels in wet season bananas could have been a result of faster development and high moisture content in the tissues, resulting in lower dry matter content and hence lower soluble sugars content.

Cultural factors and practices including mulching, irrigation, fertilization influence the quality of harvested plants (Kader, 2002). Fertilizer treatments can influence plant development with subsequent effects on fruit flavor (Mattheius \& Fellman, 1999). One of the mineral nutrients known to have a profound effect on fruit quality and postharvest behavior is nitrogen. High nitrogen associated with conventional production systems (CPS) in the present study is often associated increased succulence and poor keeping quality. In citrus, increasing nitrogen and phosphorus supply was reported to result in lower titratable acidity and ascorbic acid, while increased potassium fertilization increased acidity and ascorbic acid content (Arpaia, 1994; Lee \& Kader, 2000). In apples and pears, high nitrogen fertilization was shown to result in a decrease in firmness (Blanpied et al., 1978; Prasad et al., 1988). In the present study flesh firmness of fruits from CPS (both cultivars) was generally higher compared to LCPS bananas. Other studies also show that nitrogen fertilization affects fruit flavor components. In 'd'Anjou' pear, previous studies showed that flavor ratings of the fruit decreased with increased nitrogen fertilization (Raese, 1977). Fruit flavor ratings conducted after 7 months' storage were negatively correlated with leaf nitrogen $(\mathrm{N})$ although lower $\mathrm{N}$ treatments also resulted in smaller fruit size. This example illustrates the grower's dilemma in that, although fruit flavor is an important attribute of overall quality, size is much easier to evaluate and is one of the parameters determining grower returns. While farmers in CPS strive to achieve large fruit sizes and higher yields through high nitrogen fertilizer regimes this probably comes at the expense of fruit flavor. It would then be assumed that LCPS with low $\mathrm{N}$ fertilization from organic sources would have higher flavor ratings due to the higher sugar to acid ratio. However, the panelists in the sensory evaluation did not discriminate between LCPS and CPS. Unlike in LCPS, pesticides and insecticides are used judiciously in CPS to control pests and diseases. The use of pesticides may not directly affect fruit composition but may indirectly affect it due to delayed or accelerated fruit maturity (Kader, 2002). While flavor did not influence discrimination between LCPS and CPS bananas by the sensory panelists, low use of pesticide in LCPS makes the fruits a preferred choice for consumers due to the perceived safety attributes.

Within each commodity, there is a range of genotypic variation in composition, quality and postharvest potential (Kader, 2002). Genetic factors have a direct influence on the texture and flavor of fruits of fruits and vegetables (Mattheius \& Fellman, 1999; Sams, 1999). In the present study, slight varietal differences were observed between 'Williams' and 'Grande naine'. 'Grande naine' generally had higher starch content and titratable acidity than 'Williams'. Similarly, moisture content of the raw pulp was generally higher in 'Grande naine'. These differences point to genetic variability within a given plant species. Cultivars within a given species have been 
reported to show variability in composition, quality and postharvest potential. In banana, differences in chemical and nutritional composition between 'Gran Enana' and 'Pequeña Enana' were reported by Forster et al. (2002). Some differences in the sensory attributes including aroma, taste and mouth feel have also been reported between banana cultivars (Cano et al., 1997). In the present study, the untrained panel who were enlisted for sensory evaluation had preference for 'Williams' over 'Grande naine', in all the sensory attributes investigated; sweetness, flavor and general preference. While instrumental analyses revealed some level of superiority LCPS over CPS bananas, the ratings by sensory panelists did not reflect this superiority. Cultivar differences and the complexity of the relationship between sensory and instrumental analyses are illustrated by research reported for tomato (Lycopersicon esculentum Mill.) fruit. Cultivar differences in soluble solids, titratable acidity, $\mathrm{pH}$ and concentrations of individual sugars, acids and volatile compounds were detectable but analytical values did not correlate well with sensory scores for all cultivars (Stevens et al., 1977).

\section{References}

Arpaia, M. L. (1994). Preharvest factors influencing postharvest quality of tropical and subtropical fruits. Hortscience, 29, 982-985

Baker, B. P., Benbrook, C. M., \& Groth, E. (2002). Pesticide residues in conventional, integrated pest management (IPM) - grown and organic foods: insights from three US data sets. Food Add. Contam, 19, 427-446. http://dx.doi.org/10.1080/02652030110113799

Blanpied, G. D., Bramlage, W. J., Dewey, D. H., LaBelle, R. L., Massey, L. M., Mattus, G. E., ... Watada, A. E. (1978). A standardized method for collecting apple pressure test data. New York's Food and Life Sciences Bulletin \#74.

Chillet, M., De Lapeyre De Bellaire, L., Dorel, M., Joas, J., Dubois, C., Marchal, J., \& Perrier, X. (2000). Evidence for the variation in susceptibility of bananas to wound anthracnose due to Colletotrichum musae and the influence of edaphic conditions. Scientia horticulturae, $86(1), \quad 33-47$. http://dx.doi.org/10.1016/S0304-4238(00)00138-2

Forster, M. P., Rodríguez, E., \& Carlos, R. D. (2002). Differential characteristics in the chemical composition of bananas from Tenerife (Canary Islands) and Ecuador. J. Agric. Food Chem. 50, 7586-7592. http://dx.doi.org/10.1021/jf0257796

Harding, P. L., Sunday, M. B., \& Davis, P. L. (1959). Seasonal changes in Florida tangelos. US Department of Agriculture Technical Bulletin 1205.

Hartman, H. (1924). Studies relating to the harvesting and storage of apples and pears. Oregon Agric. Exp. Sta. Bull. 206.

Kader, A. A. (2002). Fruits in the global market. In M. Knee (Ed.), Fruit quality and its biological basis (pp. 1-17). UK: Sheffield Academic Press.

Lee, S. K., \& Kader, A. A. (2000). Preharvest and postharvest factors influencing vitamin C content of horticultural crops. Postharv. Biol. Technol.

Lester, G. E. (2006). Organic versus conventionally grown produce: quality differences, and guidelines for comparison studies. Hortscience, 41, 296-300.

Mattheis, J. P., \& Fellman, J. K. (1999). Preharvest factors influencing flavor of fresh fruits and vegetables. Postharvest Biol. Technol, 25, 227-232. http://dx.doi.org/10.1016/S0925-5214(98)00087-8

Meilgaard, M., Civille, C. V., \& Carr, T. (1991). Sensory Evaluation Techniques (2nd ed). Boca Raton, FL: CRC Press.

Nyanjage, M. O., Wainwright, H., Bishop, C. F. H., \& Cullum, F. J. (2000). A comparative study on the ripening and mineral content of organically and conventionally grown Cavendish bananas. Biol. Agric. Hort., 18, 221-234. http://dx.doi.org/10.1080/01448765.2001.9754885

Plotto, A., \& Narciso, J. A. (2006). Guidelines and acceptable postharvest practices for organically grown produce. Hortscience, 41, 287-291.

Prasad, M., King, G., \& Spiers, M. (1988). Nutrient influence on storage quality. Proc. NZKA Nat. Res. Conf., Rotorua, July 1988. New Zealand Kiwi Fruit Special Publ., 2, 22-24.

Raese, J. T. (1977). Response of young 'd'Anjou' pear trees totriazine and triazole herbicides and nitrogen. $J$. Am. Soc.Hortic. Sci., 102, 215-218. 
Rembialkowska, E. (2003). Organic farming as a system to provide better vegetable quality. Acta Hort., 604, 473-479.

Rose, D. H., Haller, M. H., \& Harding, P. L. (1934). Relation of temperature of fruit to firmness in strawberries. Proc. Am. Soc. Hortic. Sci., 32, 429-430.

Sams, C. E. (1999). 'Preharvest factors affecting postharvest texture'. Postharvest Biology and Technology, 15, 249-254. http://dx.doi.org/10.1016/S0925-5214(98)00098-2

Stevens, M. A., Kader, A. A., Albright-Holton, M., \& Algazi, M. (1977). Genotypic variation for flavor and composition in fresh market tomatoes. J. Am. Soc. Hortic. Sci., 102, 680-689.

Suzuno, H., \& Ishida, H. (2005). Characteristics of components associated with the flavor and taste of bananas cultivated in high altitude region. Nippon Shokuhin Kagaku Kogaku Kaishi, 52, 479-484. http://dx.doi.org/10.3136/nskkk.52.479

Thompson, A. K. (2003). Fruits and vegetables: Harvesting, handling and storage. Oxford, UK: Blackwell publishing Ltd.

Worthington, V. (2001). Nutritional quality of organic versus conventional fruits, vegetables and grains. J. Alt. Complem. Med., 7, 161-173. http://dx.doi.org/10.1089/107555301750164244

\section{Appendix}

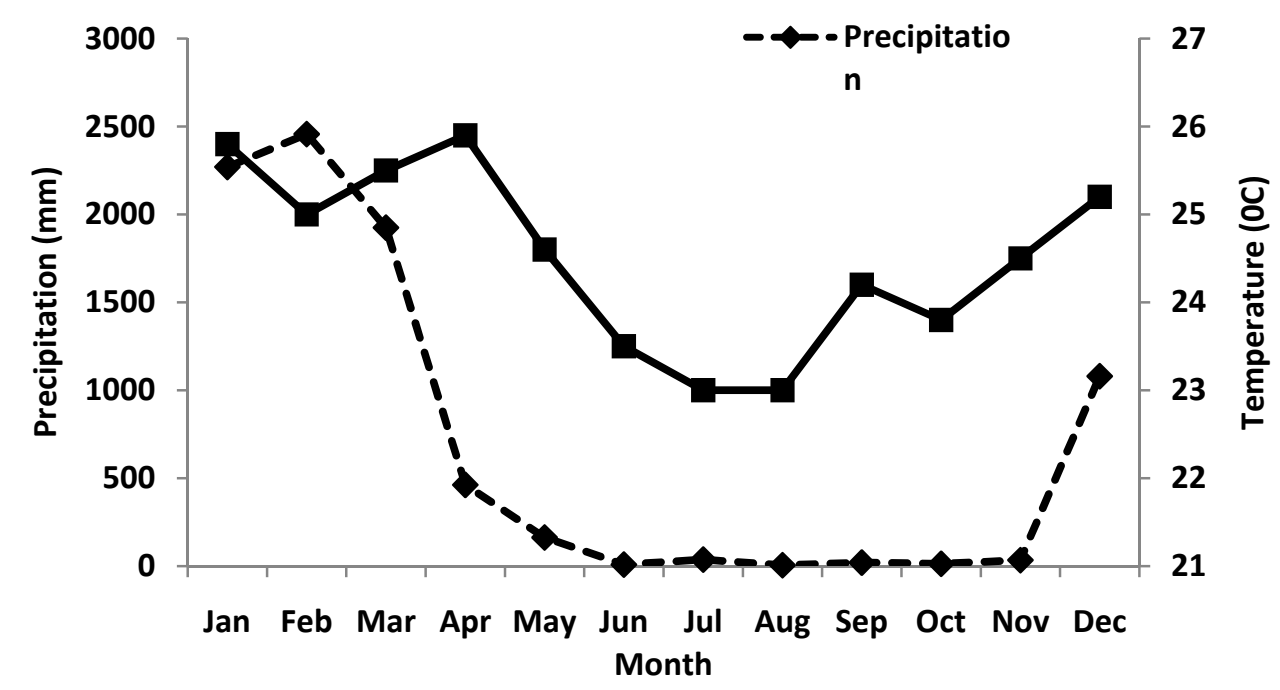

Appendix 1. Precipitation and temperature statistics in Pichilingue district of Ecuador during the experimental period. Dry season = May to early December; wet season = late December to April 